\title{
TO ASSESS THE EFFECTIVENESS OF PLANNED TEACHING PROGRAMME ON RISK FACTORS OF CORONARY ARTERY DISEASE (CAD) TO CREATE KNOWLEDGE AMONG ADMINISTRATIVE EMPLOYEES.
}

\section{Mrs Anita Meena}

Assistant Lecturer, Jeevandeep School of Nursing, Varanasi u.p.

\begin{abstract}
Corresponding email: :- : anitamn22.am@gmail.com, sharmashivani@yahoo@ca
\end{abstract}
\begin{abstract}
:
Introduction: Coronary artery disease continues to be a major health problem all over the world. It began its march in the United States in the early 1920s, in United Kingdom and in other parts of the Europe later. World Health Organization reported that cardiovascular diseases will be the largest cause of death and disability by 2020 . Coronary artery disease (CAD) is common in people with diabetes mellitus. In the 1976-80 National Health and Nutrition Examination Survey II, the prevalence of angina was higher in people with than in those without diabetes. The 1989 U. S. National Health Interview Study showed a higher prevalence of CAD in people with diabetes.

Material and Methods : The method adopted for the present study was Quasi Experimental research design. this design was adopted to assess the knowledge gain regarding the risk factors of CAD of 60 adminstrative employees of selected college of tumkur district this approach would help yhe investigator to assess the effect of specific intervention that is information booklet on the variavle that is knowledge of adminstrative employees regarding CAD In selected college of Tumkur District. in this study sample were draw by using simple sampling method data was collected by using structured knowledge questionnaire.

Result : The data themselves do not provide us with answer to our research question. Ordinarily the amount of data collected in a study is too expensive to be reliably described . in order to meaningfully answer the reasearch questions. the data must be processed and analysed systemetically.

CONCLUSION : The following conclusions were drawn on the basis of the findings of the study are Most of the sample( experimental group-80\%, control group-86. 7\%) had moderate knowledge regarding riskf actors of CAD in the pre-test. Where as the mean percentage post-test scores and the modified gain scores in all areas were found to be high in experimental group only.

Keyword : Assess, effectivness, information booklet, admistrative employees, Coronary artery disease, questionnaire.WHO, Coronary heart disease, cardiovasculer disease.
\end{abstract}

\section{INTRODUCTION}

The incidence of cardiovascular diseases (CVD) is on the rise in modern world. Coronary Artery Disease (CAD) is a leading cause of cardio vascular mortality worldwide with $>4.5$ million deaths occurring in developing world. Despite a recent decline in developed countries, both CAD mortality and prevalence of CAD risk factors continue to rise rapidly in developing countries ${ }^{1}$.

CAD was the leading cause of morbidity and the fifth leading cause of mortality in the world. There are several factors contributing to its steady increase the common one is, industrialization leading to urbanization general improvement in economic status and its collective effects on peoples life style among men and women and across all ethical and ethnic groups, CAD is the world's leading killer ${ }^{2}$.

The goal of WHO global strategy is to effectively control CVD risk factors to reduce the burden of the fast growing cardiovascular epidemic particularly in developing countries ${ }^{3}$.

The common cardio vascular diseases that cause increased burden all over the world are coronary artery disease (CAD). Coronary artery disease is one of the top ten causes of mortality with 6.1 million deaths per year ${ }^{4}$. 


\section{NEED FOR THE STUDY}

CAD epidemics are essentially preventable according to existing knowledge. In the majority of developed countries CAD mortality has fallen by a third or half in the last two decades. In USA the SMR (Standard mortality rate) of CAD is decline by $54 \%$. The rate of decline in CAD was substantially greater among educated. This is a clear proof that the ravages of CAD can be reduced with appropriate measures. On analyzing the responsible factors, it was found that more than half of the early decline of CAD in the USA was due to changes in risk factors, mainly from the modification of lifestyle ${ }^{7}$.

Several studies have found that the knowledge about the risk factors of CHD of the population under study was inadequate. Further the clinical experience of the researcher also shows that in general, people have the lack knowledge about the risk factors of CAD. It is the adult group, which suffers more from CHD, just because of their unhealthy life styles. Knowledge, awareness of risk status, scenario of disease and planned teaching programme about the risk factors of CAD can motivate people to take preventive measures. Very few studies have been done with regards to create knowledge regarding to risk factors of $\mathrm{CAD}$ and evaluation of effectiveness of planned teaching programme in India. It is obvious that the need for community awareness is very high and no longer can be delayed. Therefore, the researcher felt a strong need to assess the knowledge and preventive health behaviour of risk factor of CAD and the effectiveness of planned teaching programme regarding risk factors of CAD to create knowledge among administrative employees.

\section{OBJECTIVES}

1. Assess the knowledge regarding risk factors of CAD among administrative employees

2. Find the effectiveness of planned teaching programme between pre-test \& post-test knowledge regarding risk factors of CAD.

3. To compare the effectiveness of planned teaching programme between the experimental and control group on knowledge of risk factor of CAD.

\section{MATERIALAND METHOD}

Find the association of pre-test level of knowledge with the demographic variables. The method adopted for the present study was Quasi Experimental research design. this design was adopted to assess the knowledge gain regarding the risk factors of CAD of 60 adminstrative employees of selected college of tumkur district this approach would help yhe investigator to assess the effect of specific intervention that is information booklet on the variavle that is knowledge of adminstrative employees regarding CAD In selected college of Tumkur District. in this study sample were draw by using simple sampling method data was collected by using structured knowledge questionnaire

\section{RESULT}

The data themselves do not provide us with answer to our research question. Ordinarily the amount of data collected in a study is too expensive to be reliably described . in order to meaningfully answer the reasearch questions. the data must be processed and analysed systemetically.

TABLE 1: Actual and modified knowledge gain scores in different areas of risk factors of CAD

\begin{tabular}{|c|c|c|c|c|c|c|c|c|c|}
\hline \multirow[b]{2}{*}{ Area } & \multirow[b]{2}{*}{$\begin{array}{l}\text { Maxi } \\
\text { mum } \\
\text { Score }\end{array}$} & \multicolumn{2}{|c|}{$\begin{array}{c}\text { Mean pre-test } \\
\text { score }(\%)\end{array}$} & \multicolumn{2}{|c|}{$\begin{array}{c}\text { Mean Post-test } \\
\text { score (\%) }\end{array}$} & \multicolumn{2}{|c|}{ Actual gain } & \multicolumn{2}{|c|}{$\begin{array}{c}\text { Modified gain } \\
\text { score }\end{array}$} \\
\hline & & $\begin{array}{l}\operatorname{Exp} \\
\text { group }\end{array}$ & $\begin{array}{c}\text { Contr } \\
\text { ol } \\
\text { group }\end{array}$ & $\begin{array}{c}\text { Exp } \\
\text { grou } \\
\text { p }\end{array}$ & $\begin{array}{c}\text { Control } \\
\text { group }\end{array}$ & $\begin{array}{c}\operatorname{Exp} \\
\text { group }\end{array}$ & $\begin{array}{l}\text { Contro } \\
1 \text { group }\end{array}$ & $\begin{array}{c}\operatorname{Exp} \\
\text { group }\end{array}$ & $\begin{array}{l}\text { Contro } \\
\text { I group }\end{array}$ \\
\hline Area 1 & 7 & 63.30 & 66.14 & 86.71 & 67.57 & 23.41 & 1.43 & 0.630 & 0.040 \\
\hline Area 2 & 3 & 79.00 & 66.66 & 91.00 & 70.00 & 12.00 & 3.34 & 0.570 & 0.100 \\
\hline Area 3 & 30 & 75.96 & 79.53 & 87.41 & 79.64 & 11.45 & 0.11 & 0.470 & 0.005 \\
\hline Total & 40 & 77.02 & 80.08 & 87.56 & 81.02 & 10.54 & 0.94 & 0.450 & 0.050 \\
\hline
\end{tabular}

Key:Area 1: Anatomy and physiology of heart Area 2: Non-modifiable risk factors of coronary arterial disease

Area 3: Modifiable risk factors of coronary arterial disease

The data presented in Table 6 show that the maximum modified gain for experimental group in area 1 i.e. the anatomy and physiology of heart which was 0.63 respectively followed by the "Non-modifiable risk factors of coronary arterial disease" and "Modifiable risk factors of coronary arterial disease," which were 0.57 and 0.47 . In the control group maximum modified gain was in "Non-modifiable risk factors of coronary arterial disease" (0.10). In other areas it was almost equal to nil. The minimum gain in experimental group was in "Modifiable risk factors of coronary arterial disease." The mean post-test score in experimental group in all areas of CAD was 87.56, which was higher 
than the mean pre-test score i.e. 77.02, whereas in control group mean post-test score was 81.02 which was about to same of mean pre-test score, i.e., 80.08. The overall actual gain in experimental group was 10.54 and in control group it was 0.94 . From this data, it was evident that overall mean pre-test score of control group was slight high than that of experimental group.

Area wise significance of difference

Table 2: Mean, mean difference and ' $t$ ' value of pretest and post-test knowledge score

\begin{tabular}{|c|c|c|c|c|c|c|c|c|}
\hline \multirow[b]{3}{*}{ Area } & \multicolumn{4}{|c|}{ Mean knowledge score } & \multirow{2}{*}{\multicolumn{2}{|c|}{ Mean difference }} & \multirow{2}{*}{\multicolumn{2}{|c|}{ - }} \\
\hline & \multicolumn{2}{|c|}{ Pre-test } & \multicolumn{2}{|c|}{ Post-test } & & & & \\
\hline & $\begin{array}{c}\text { Exp } \\
\text { grou } \\
\text { p }\end{array}$ & $\begin{array}{c}\text { Control } \\
\text { group }\end{array}$ & $\begin{array}{l}\text { Exp } \\
\text { group }\end{array}$ & $\begin{array}{c}\text { Control } \\
\text { group }\end{array}$ & $\begin{array}{l}\text { Exp } \\
\text { group }\end{array}$ & $\begin{array}{c}\text { Control } \\
\text { group }\end{array}$ & $\begin{array}{l}\text { Exp } \\
\text { group }\end{array}$ & $\begin{array}{r}\text { Contro } \\
\text { I group }\end{array}$ \\
\hline Area 1 & 4.43 & 4.63 & 6.07 & 4.73 & 1.64 & 0.10 & 7.527 & 1.114 \\
\hline Area 2 & 2.37 & 2.00 & 2.73 & 2.10 & 0.36 & 0.10 & 3.003 & 1.796 \\
\hline Area 3 & 22.03 & 22.27 & 27.10 & 22.30 & 5.07 & 0.03 & 10.467 & 1.114 \\
\hline Total & 28.50 & 28.80 & 35.90 & 29.17 & 7.40 & 0.37 & 13.717 & 1.114 \\
\hline
\end{tabular}

$\mathrm{t}_{29}=2.01, \mathrm{P}<0.05$

Key: Area 1:Anatomy and physiology of heart

Area 2: Non-modifiable risk factors of coronary arterial disease

Area 3: Modifiable risk factors of coronary arterial disease

The data presented in Table 8 that the mean post-test scores of experimental group was higher in the all areas of risk factors of CAD than their pre-test knowledge scores. ' $t$ ' values computed in all areas were significant at 0.05 level. This showed that in experimental group, there was a significant gain in the knowledge scores in all areas of CAD. Therefore the planned teaching programme was an effective method of increasing the participant's knowledge on risk factors of CAD
Findings related to knowledge of sample regarding preventions and management of coronary artery disease.

- Findings of the study show that in the experimental group majority of participants $(80 \%)$ were in moderate level of knowledge, whereas in control group majority (86.7) also were in moderate level of knowledge.

-There was significant difference between pre-test post-test knowledge scores in experimental group only ( $\mathrm{t} 29=13.717, \mathrm{p}<0.05$ significant $)$.

-There was the effectiveness of planned teaching programme between experimental group and control group $(\mathrm{t} 58=12.179, \mathrm{p}<0.05$ highly significant $)$.

\section{CONCLUSION}

The following conclusions were drawn on the basis of the findings of the study are Most of the sample( experimental group- $80 \%$, control group- $86.7 \%$ )

had moderate knowledge regarding riskf actors of CAD in the pre-test. Where as the mean percentage post-test scores and the modified gain scores in all areas were found to be high in experimental

\section{REFERANCEE}

1. Murray CJ, Lopez AD. The global burden of disease: A Comprehensive assessment of mortality and disability from disease, injuries and risk factors in 2000 and projected to 2020 J Health Risk Manag 2000.

2. Anand S. The global burden of cardiovascular disease. [Online]. Available from: URL:

3. Yavagal ST. Prevention is better than cure. [Online]. Available from: URL:.

4. Park K. Park's text book of preventive and social medicine. 16th ed. Jabalpur: Banarsidas Bhanot Co.; 2000.

5. Gupta R, Gupta VP. Meta analysis of coronary heart disease prevalence in India. Indian Heart Journal 2001 Jan;48:241-5. 